\title{
Waste Bricks Applied as Removal Agent of Basic Blue 41 from Aqueous Solutions: Base Treatment and Their Regeneration Efficiency
}

\author{
Fethi Kooli ${ }^{1, *}$, Yan Liu ${ }^{2}$, Mostafa Abboudi ${ }^{3}$, Hicham Oudghiri Hassani ${ }^{4}$, Souad Rakass ${ }^{3}$, \\ Sheikh Muhammad Ibrahim ${ }^{5}$ and Fahd Al Wadaani ${ }^{3}$ \\ 1 Taibah University-Al-Mahd Branch, Community College, Al-Mahd 42112, Saudi Arabia \\ 2 Institute of Chemical and Engineering Sciences, 1 Pesek Road, Jurong Island, Singapore 627833, Singapore; \\ liu_yan@ices.a-star.edu.sg \\ 3 Department of Chemistry, Taibah University, POBox 30002, Al-Madinah Al-Munawwarah 41147, Saudi \\ Arabia; abboudi14@hotmail.com (M.A.); rakass_souad@yahoo.fr (S.R.); fwadaani@taibahu.edu.sa (F.A.W.) \\ 4 Engineering Laboratory of Organometallic and Molecular Materials, Faculty of Sciences, Chemistry \\ Department, University Sidi Mohamed Ben Abdellah, Po. Box 1796 (Atlas), Fez 30000, Morocco; \\ oudghiri_hassani_hicham@yahoo.com \\ 5 Department of Chemistry, Faculty of Science, Islamic University of Madinah, Al-Madinah Al-Munawwarah \\ 42351, Saudi Arabia; mdibrahi@gmail.com \\ * Correspondence: fkooli@taibahu.edu.sa; Tel: +966569442963
}

Received: 13 February 2019; Accepted: 21 March 2019; Published: 24 March 2019

\begin{abstract}
Waste brick materials were applied as removal materials of basic blue 41 (BB-41) from artificially contaminated water. They were characterized by different techniques prior their use. A series of removal tests were carried out at different conditions, such as a dosage effect, $\mathrm{pH}$ value, initial concentrations, and chemical treatment. The removal results indicated that the two untreated waste bricks had limited removal capacities of basic blue 41, ranging from 19 to $30 \mathrm{mg} / \mathrm{g}$. However, these values were improved upon treatment with $\mathrm{NaOH}$ solution or by increasing the removal temperature. Waste brick collected from the Medina area (Med-WB) exhibited higher removal capacity compared to the one collected from the Jeddah area (Jed-WB), with a maximum removal capacity of $60 \mathrm{mg} / \mathrm{g}$ at $60^{\circ} \mathrm{C}$. The $\mathrm{pH}$ of the BB- 41 solution also played an important factor, as it improved the removal amounts from $25 \mathrm{mg} / \mathrm{g}$ to $45 \mathrm{mg} / \mathrm{g}$ at initial concentration of $200 \mathrm{mg} / \mathrm{L}$. The regenerative process was studied using oxidative reaction of the removed basic blue 41 with a solution of oxone and cobalt nitrate. The efficiency was maintained after 5 runs for Med-WB, with a slight variation of $25 \%$, while it felt to $50 \%$ for Jed-WB material after three runs. These data indicate that the waste brick materials present as potential candidates for the dye removal and their origin has to be identified.
\end{abstract}

Keywords: waste bricks; removal; basic blue 41; thermodynamic parameters; adsorption; base activation; regeneration

\section{Introduction}

The water demand doubles globally every two decades, due to the rapid increase of populations, industrial activities, and the decrease of rainfall [1]. The exploration of safe water sources to overcome the scarcity of water has been a global challenge for many countries [2]. Waste water reclamation and recycling were proposed as an alternative way to reduce the water demand in irrigation, industries, and domestic uses [3]. The textile industry presented an important share in total water consumption, as during dyeing processes about $20-40 \%$ of these dyes remain in the effluents [4] The presence of dyes 
in effluents causes a lot of pollution in water. Many dyes are carcinogenic and affect the life of aquatic organisms [5,6].

Many physical and chemical processes for color removal have been applied, including coagulation and flocculation, biosorption, photo-decomposition and ultrafiltration, oxidizing agents, membrane, and electrochemical. The advantages and disadvantages of each technique have been extensively reviewed [7]. The adsorption process is an efficient and economic process for removing dyes, pigments, and other colorants, particularly for its initial low cost, simplicity, ease of operation, and insensitivity towards toxic substances $[8,9]$. Many types of adsorbents are effective in removing color from aqueous effluents, with activated carbon as the most commonly used one in industrial wastewater treatment systems, mainly because of its large specific surface area $[10,11]$. However, its major drawback is its relatively high cost. This has encouraged many researchers to search for cheaper substitutes, such as coal, fly ash, silica gel, wool wastes, agricultural wastes, oak leaves, wood wastes, sewage sludge, and clay materials [9-12]. Clays, such as sepiolite, bentonite, montmorillonite, and smectite are being considered as alternative low-cost adsorbents with high chemical and mechanical stability, small particle sizes, lamellar structures, and negatively charged surfaces. This makes them good cation adsorbents with large specific surface areas for ion exchange or electrostatic attraction. The chemical nature and pore structure usually determine the sorption ability of clays [13-15].

To enhance their removal properties, the modification of clay minerals could be achieved by different physical or chemical methods. The type of modification affects the removal properties of the obtained materials. For instance, the acid activation process, based on chemical alteration of the starting clay minerals, led either to an improvement or reduction of the removal properties for basic dyes [15-18]. Modification of clay minerals was done by insertion of an alkyl-ammonium cation or cationic surfactant into the interlamellar spacing. These are called as organoclays. These organoclays have a lower thermal stability due to the decomposition of organic molecules in the range of 200 to $400{ }^{\circ} \mathrm{C}$ and were used for the removal of acidic dyes [19]. The pillaring process was proposed to modify the chemical composition and enhance the thermal stability of the starting clay minerals. It consisted of maintaining the clay sheets, separated apart after introducing the polyoxocation metal cations, and was followed by calcination of the obtained materials. This process would introduce additional adsorption sites between the clay sheets and make them accessible to the dye cations [20]. The calcination of raw clay was proposed as an alternative way to modify its adsorption properties [21,22]. In addition, this method was used to regenerate spent clays after the removal process [23]. The calcination temperature was in the range of 200 to $500{ }^{\circ} \mathrm{C}$. Above this temperature, the layered structure was collapsed and the clay mineral was transformed to an amorphous silica phase that exhibited low adsorption capacity [22]. Thus, further calcination of clay minerals at higher temperatures between 800 to $1000^{\circ} \mathrm{C}$ was not undertaken. The brick industry is based on a higher temperature treatment, between 800 to $1000^{\circ} \mathrm{C}$, to transform the ingredient mixture (mainly clay minerals and sand) into a stable material [23]. The production process of bricks generates amounts of solid wastes and were used in different applications, such as a substitution for clinker [24-26].

In environmental applications, the waste bricks were used in the removal of different pollutants, such as mercury, fluorine, ammonia, and phosphorous, in addition to the colorant dyes, such methylene blue, basic blue, and pharmaceutical pollutants, such as diclofenac [27-32]. The pre-treatment of the waste brick by acid solution or basic solution has improved its removal properties of copper cations and basic blue dye $[33,34]$. The coating of the waste brick by iron or titanium oxide has also enhanced its photo-degradation of methylene blue dye $[35,36]$.

In a previous study, the ability to use the brick waste as removal agent for the basic blue 41(BB-41) was investigated [33]. For this purpose, the waste was collected from a local brick manufacturer. The waste was treated with different solutions of sodium hydroxide or sulfuric acid. The treatment of waste brick with sodium hydroxide solution improved the removal properties of the waste brick towards basic blue 41 [33] due to the increase of hydroxide anions, in other words, to the increase of the negative charges on the surfaces. The origin of clay minerals affected its chemical properties and its resulting 
derived materials [37-40]. The resulting bricks varied in chemical and textural compositions from one place to another, depending on their geological origin and the presence of organic and inorganic impurities [41-43]. This study was carried out to test the hypothesis that the waste bricks obtained from different areas, using different clays, could affect their physiochemical properties and if the resulting waste materials would be effective in the removal of BB-41 in various conditions. The testing of regenerative capacity after the first BB-41 removal was investigated, using a friendly method to the environment [19]. The materials were characterized by different techniques before their use and to correlate these properties to the removal efficiency.

\section{Experimental Part}

\subsection{Materials}

The waste bricks were collected from two different regions. One waste brick was collected from a manufacture situated in the Medina region, identified as Med-BW, and the second one was collected about $400 \mathrm{~km}$ North of Medina, close to Jeddah area, and assigned as Jed-WB. Both regions are located in Saudi Arabia. The waste bricks were broken into pieces using a hammer. The powdered brick wastes were then stored in containers and screened through different sized sieves [33]. The basic blue 41 dye was provided by Acros Organics and used as received.

The modification of $\mathrm{WB}$ was performed using a $\mathrm{NaOH}$ solution $(4 \mathrm{M})$ as reported in a previous study [33]. One gram of $\mathrm{WB}$, with diameter less than $0.6 \mathrm{~mm}$, was stirred in a specific volume of $\mathrm{NaOH}$ solution, then filtered and washed extensively with distilled water. The samples will be assigned as B-Jed-BW and B-Med-BW.

\subsection{Basic Blue-41 Removal Experiments}

The removal process for basic blue 41 was performed as reported in previous studies $[19,33]$. A stock solution of $1000 \mathrm{mg} / \mathrm{L}$ was prepared by dissolving 1 gram of BB-41 solid dye into 1 liter of distilled water. The stock solution was further diluted to the desired concentrations. Batch experiments were conducted by shaking $0.1 \mathrm{~g}$ of waste brick with $10 \mathrm{~mL}$ of aqueous dye solution of each concentration (varying from $50 \mathrm{ppm}$ to $1000 \mathrm{ppm}$ ) overnight, in an electric shaker water bath, at a temperature of $25^{\circ} \mathrm{C}$. The effective contact time for the removal experiments was 6 hours [33], however, a prolonged period of time was adopted to ensure that the equilibrium was attained. After equilibrium, the solution was recovered by centrifugation and analyzed by a UV-visible spectrophotometer. Blank experiments were also conducted by using dye solutions without adsorbents to ensure that no dye was adsorbed into the glass tubes. All removal experiments were performed in triplicate and the mean values were used in data analysis. The errors percentages were about $5 \%$.

\subsection{Regeneration Tests}

The regeneration process followed the method reported in a previous study [33]. It consists of treating fresh spent waste brick in $10 \mathrm{ml}$ of a Cobalt nitrate solution of $(10 \mathrm{mM})$ and $12 \mathrm{mg}$ of oxone $\left(2 \mathrm{KHSO}_{5} \times \mathrm{KHSO}_{4} \times \mathrm{K}_{2} \mathrm{SO}_{4}\right.$, Alfa Aesar, $4.7 \%$ active oxygen) after the removal run. The oxone was added into the mixture to degrade the removed BB-41. The reaction was stirred for $30 \mathrm{~min}$. The solid was separated by centrifugation and add to $20 \mathrm{~mL}$ of a fresh solution of BB-41, with a concentration of $200 \mathrm{mg} / \mathrm{L}$, overnight and the same procedure was repeated. The concentration at equilibrium $\left(\mathrm{C}_{\mathrm{e}}\right)$ was measured as described above.

\subsection{Characterization}

The XRD technique was used to identify the mineralogical phases in the WB materials. The patterns were collected by a Brucker Advance 8 equipped with a $\mathrm{Cu}$ tube corresponding to a wavelength of $1.5412 \AA$. The chemical composition, in term of $w \%$ of metal oxides, was estimated using Brucker $x$-ray fluorescence (XRF) equipment (S4 Explorer model). The FTIR spectra were collected 
with a FTIR spectrometer model from Shimadzu, using the KBr technique. The thermal gravimetric analysis studies were performed using a TA Instruments calorimeter, model SDT2960, in the range of $25^{\circ} \mathrm{C}$ to $800{ }^{\circ} \mathrm{C}$, at heating rate of $10^{\circ} \mathrm{C}$, and under air atmosphere. The morphology of the materials was examined by a scanning electron microscope (SEM) from JEOL, model JSM-6700F. The specific surface area, the total pore volume, and the average pore diameter values were estimated from the nitrogen adsorption isotherms. The isotherms were obtained using a micromeritics device, model ASAP 2020. The BET (Brunauer, Emmett and Teller) equation was used to estimate the values of the specific surface area $\left(\mathrm{S}_{\mathrm{BET}}\right)$ and the total pore volume was measured at a relative pressure value of 0.95 .

The $C_{e}$ (concentration at equilibrium) was estimated from the calibration curve of the BB-41 solution using the Lambert law. The absorbance was measured by a Varian UV-visible spectrophotometer, Cary $100 \mathrm{C}$ model, at a wavelength $\left(\lambda_{\max }\right)$ value of $610 \mathrm{~nm}$.

\section{Results and Discussion}

\subsection{Characterization of the Used WB.}

From the XRF, chemical analysis of the raw WBs and those modified with $\mathrm{NaOH}$ are presented in Table 1. It was found that Med-WB and Jed-WB contained considerable amounts of $\mathrm{SiO}_{2}$, varying between $50 \%$ and $59 \%$, with a general tendency that more $\mathrm{SiO}_{2}, \mathrm{Al}_{2} \mathrm{O}_{3}$, and $\mathrm{Fe}_{2} \mathrm{O}_{3}$ oxides were present in Jed-BW, compared to Med-WB. However, Med-BW contained more $\mathrm{K}_{2} \mathrm{O}, \mathrm{CaO}$, and $\mathrm{Na}_{2} \mathrm{O}$ percentages. This variation could be related to different starting clays used to prepare the bricks. The silica content was close to that reported for other brick materials from different origins. [33,34,41].

Table 1. Metal oxides (weight \%) contents of different waste bricks before and after treatment with $\mathrm{NaOH}$ solution.

\begin{tabular}{cccccccc}
\hline Samples & $\mathbf{S i O}_{2}$ & $\mathbf{A l}_{\mathbf{2}} \mathbf{O}_{\mathbf{3}}$ & $\mathbf{M g O}$ & $\mathbf{F e}_{\mathbf{2}} \mathbf{O}_{\mathbf{3}}$ & $\mathbf{C a O}$ & $\mathbf{K}_{\mathbf{2}} \mathbf{O}$ & $\mathbf{N a}_{\mathbf{2}} \mathbf{O}$ \\
\hline Jed-WB & 58.28 & 23.72 & 1.53 & 12.32 & 2.43 & 0.89 & 0.72 \\
Med-WB & 54.60 & 17.57 & 4.48 & 9.42 & 7.40 & 2.53 & 2.19 \\
B-Med * & 54.88 & 17.24 & 4.70 & 9.70 & 7.31 & 2.43 & 2.10 \\
B-Jed * & 57.54 & 23.41 & 1.32 & 12.34 & 2.38 & 0.56 & 0.53 \\
\hline \multicolumn{7}{c}{ * stands for sample treated with $\mathrm{NaOH}$ solution. }
\end{tabular}

Generally, the basic treatment of non-calcined clays results in the dissolution of the amorphous silica phase [43,44]. After treatment with the $\mathrm{NaOH}$ solution, the amount of $\mathrm{SiO}_{2}$ was slightly decreased in both $\mathrm{WB}$, indicating that $\mathrm{SiO}_{2}$ content in the WB was mainly present in crystalline phase or the silica phase was strongly attached to the brick grains [33]. The slight decrease of $\mathrm{SiO}_{2}$ percentage affected the other metal oxide percentages in similar manner.

The XRD patterns of Med-WB and Jed-WB are presented in Figure 1. It exhibited crystalline peaks consisting mainly of quartz (silica) peaks around $4.25 \AA, 3.34 \AA$, and $2.45 \AA$ [33]. The Med-WB showed a similar XRD pattern, with a lower intensity of the reflections, indicating lower crystallinity degree of later material, compared to Jed-WB (Figure 1).

The presence of quartz is due to the use of some sand particles as an additive material in brick manufacturing $[43,45]$ or as impurities in the starting mixtures. The treatment of waste bricks with base solution did not alter the general feature of the XRD patterns and the reflections related to quartz are still mainly present. The PXRD patterns of the starting mixtures before the preparation of the bricks are presented in Figure 2. The mixture of the Medina brick was mainly composed of silica phase in addition to other phases, while the mixture of the Jed brick contained smectite and kaolinite phases, in addition to silica. This difference could be the origin of the chemical analysis data. 


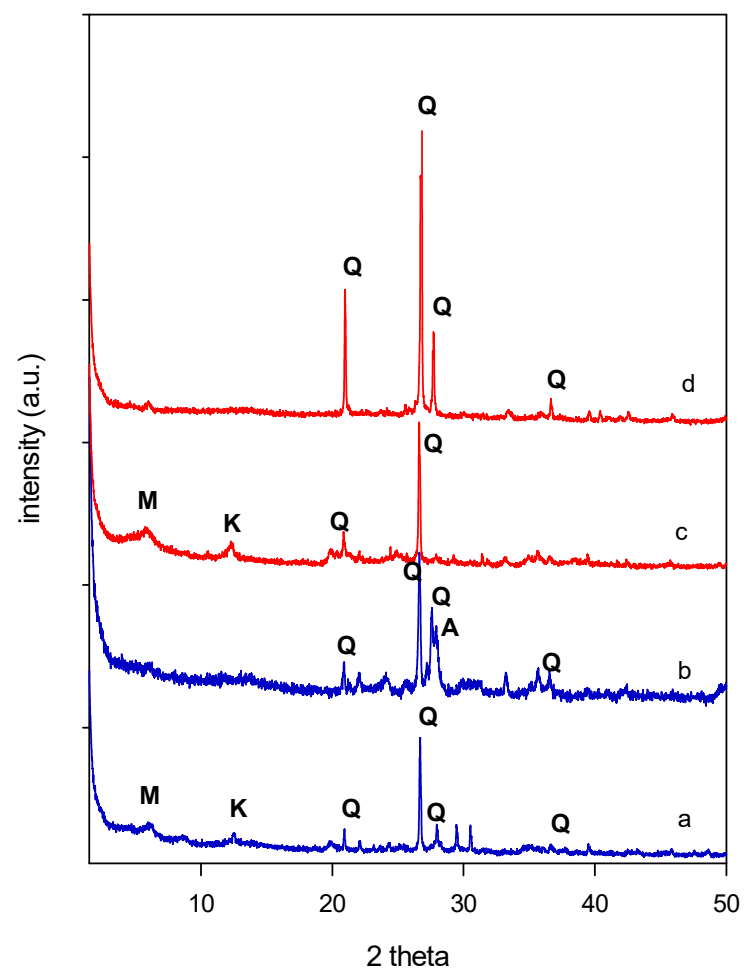

Figure 1. Powder x-ray diffraction (PXRD) patterns of (b) Med-WB and (d) Jed-WB materials. (a) and (c) correspond to Med and Jed cake mixture before firing. (Q: quartz; M: Montmorillonite; K: kaolinite; A: albite phases).

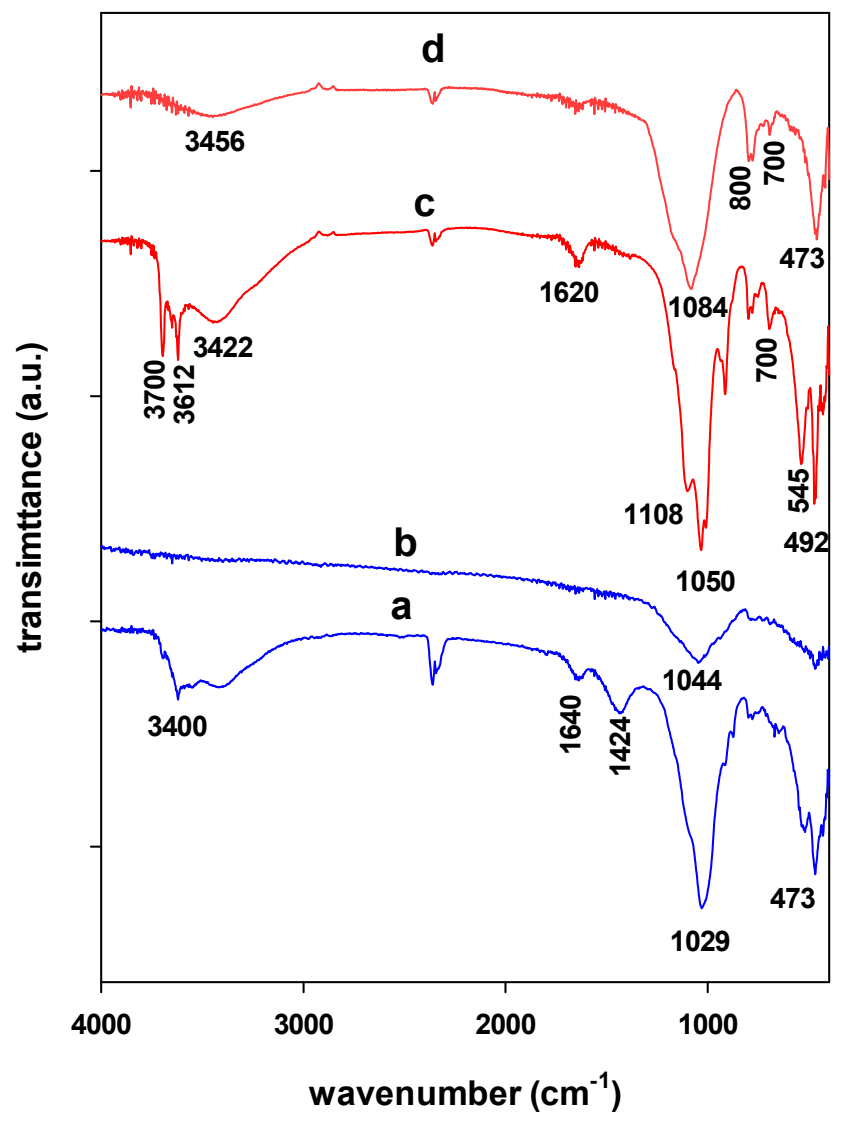

Figure 2. FTIR spectra of (b) Med-WB and (d) Jed-WB materials. (a) and (c) correspond to Med and Jed cake mixture before firing. 
The FTIR spectra of both waste bricks are presented in Figure 2. The results indicated that silica phase $\left(\mathrm{SiO}_{2}\right)$ was the prominent compound in the Med-WB and Jed-WB materials. The FTIR spectrum of Jed-WB exhibited an intense band, $1084 \mathrm{~cm}^{-1}$. This band was assigned to Si-O asymmetric stretching vibrations. The bands observed at $800 \mathrm{~cm}^{-1}$ and $700 \mathrm{~cm}^{-1}$ could be due to Si-O vibrations of the $\mathrm{SiO}_{2}$ phase. The band at $473 \mathrm{~cm}^{-1}$ could be assigned to the Si-O-Si bending vibration $[46,47]$. The FTIR spectrum of Med-WB revealed bands at $1044 \mathrm{~cm}^{-1}$ and $779 \mathrm{~cm}^{-1}$, which were allocated to the asymmetric and symmetric stretching vibration of the Si-O bonds, respectively [46,47]. The presence of the band at $1084 \mathrm{~cm}^{-1}$ could indicate that the used mixture contained kaolinite clay [48]. The FTIR spectra of the two cake mixtures, before calcination, indicated that that Jed-Brick cake exhibited a different spectrum compared to Med Brick, due to the different clays in their mixtures. Indeed, the Jed Brick exhibited strong bands related to kaolinite clay mineral at $3700 \mathrm{and} 3612 \mathrm{~cm}^{-1}$ [48], in addition to the bands of silica phase. While, the Med-Brick mixture contains mainly silica with characteristic band of $1029 \mathrm{~cm}^{-1}$ and other weak bands in the ranges of 3300 to $2800 \mathrm{~cm}^{-1}$ and from 1500 to $500 \mathrm{~cm}^{-1}$ [49]. The band at $1424 \mathrm{~cm}^{-1}$ was related to carbonate materials [50]. This band was not observed in the mixture of the Jed-Brick. The hydroxyl bands at 3300 to $2800 \mathrm{~cm}^{-1}$ vanished due to the dehydroxylation during the calcination process of the mixtures and the shape of the Si-O bands changed to one broad brand, due to the formation of silica phase and other amorphous phases. The WB materials are red, which indicated the presence of iron oxide. The characteristic bands of iron oxide are reported in the range of 526 and $436-459 \mathrm{~cm}^{-1}$ [51], however, in our case, it was difficult to detect these bands, which could indicate that the iron oxide was dissolved into the silica phase, as reported in previous studies.

The FTIR spectra of the base treated samples (not shown) were similar to the raw waste bricks, indicating that the base treatment did not alter the structure of the waste bricks and the silica phase was stable during the base treatment.

The TGA curves of the starting cakes before calcinations are presented in Figure 3. The Medina cake exhibited a mass loss from room temperature (RT) to $200{ }^{\circ} \mathrm{C}$, related to the water molecules physisorbed, and a second one starting from 450 to $700{ }^{\circ} \mathrm{C}$, associated with the dehydroxylation of the used mixture and the release of carbonate materials, mainly calcium carbonate (as indicated by FTIR) [52]. The total mass loss was about $25 \%$. The Jed- brick cake exhibited similar steps, however, with a shift to low temperatures at the second mass loss. Indeed, the DTG curve exhibited a maximum temperature loss at $450{ }^{\circ} \mathrm{C}$, with a total of $15 \%$ mass loss. This difference could be related to the composition and the types of clays in both mixtures. However, the waste bricks exhibited different features and only a negligible mass loss of $2 \%$ was detected in the ranges of $100-600{ }^{\circ} \mathrm{C}$ and $600-900{ }^{\circ} \mathrm{C}$, indicating that the raw materials of bricks were fired at temperatures higher than the temperature of dehydroxylation and they were completely dehydroxylated.

The TGA of the base treated waste brick (not shown) features exhibited similar ones to the pristine materials, indicating that there was no effect of the base treatment on the structure of these materials.

The SEM micrographs, presented in Figure 4, reveal that the two WB have different morphologies, The Med-WB exhibited a compact appearance, which was free of pores and had plate-shaped grains [33]. The Jed-WB also had a compact appearance, with a different aggregation of the particles. After the treatment with the $\mathrm{NaOH}$ solution, no alterations of the particle shapes were observed for both WB materials. 


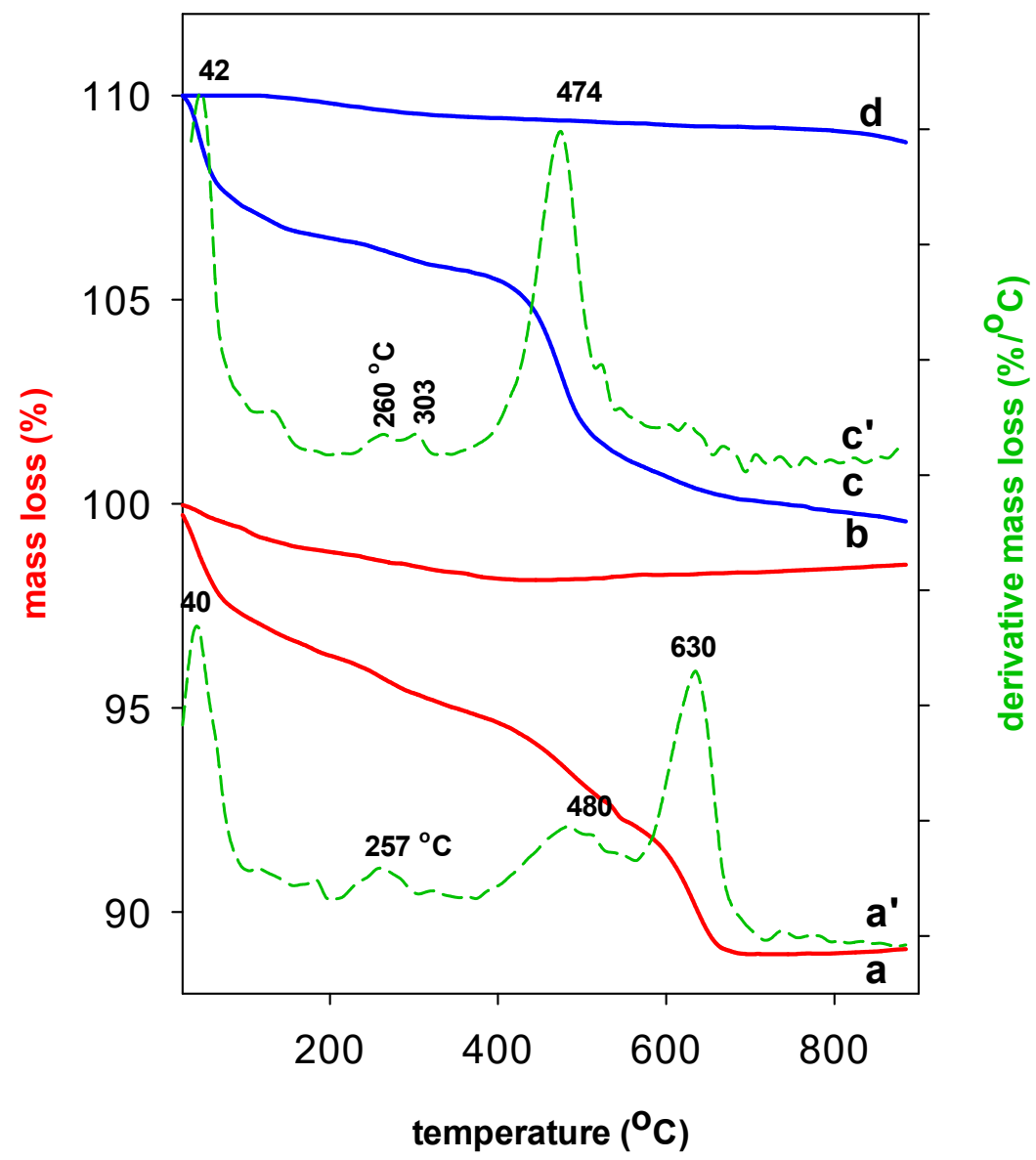

Figure 3. TGA features of (b) Med-WB and (d) Jed-WB materials. $\left(\mathbf{a}, \mathbf{a}^{\prime}\right)$ and $\left(\mathbf{c}, \mathbf{c}^{\prime}\right)$ correspond to TGA (solid lines) and DTG (dashed lines) of the Med and Jed cake mixtures before firing.
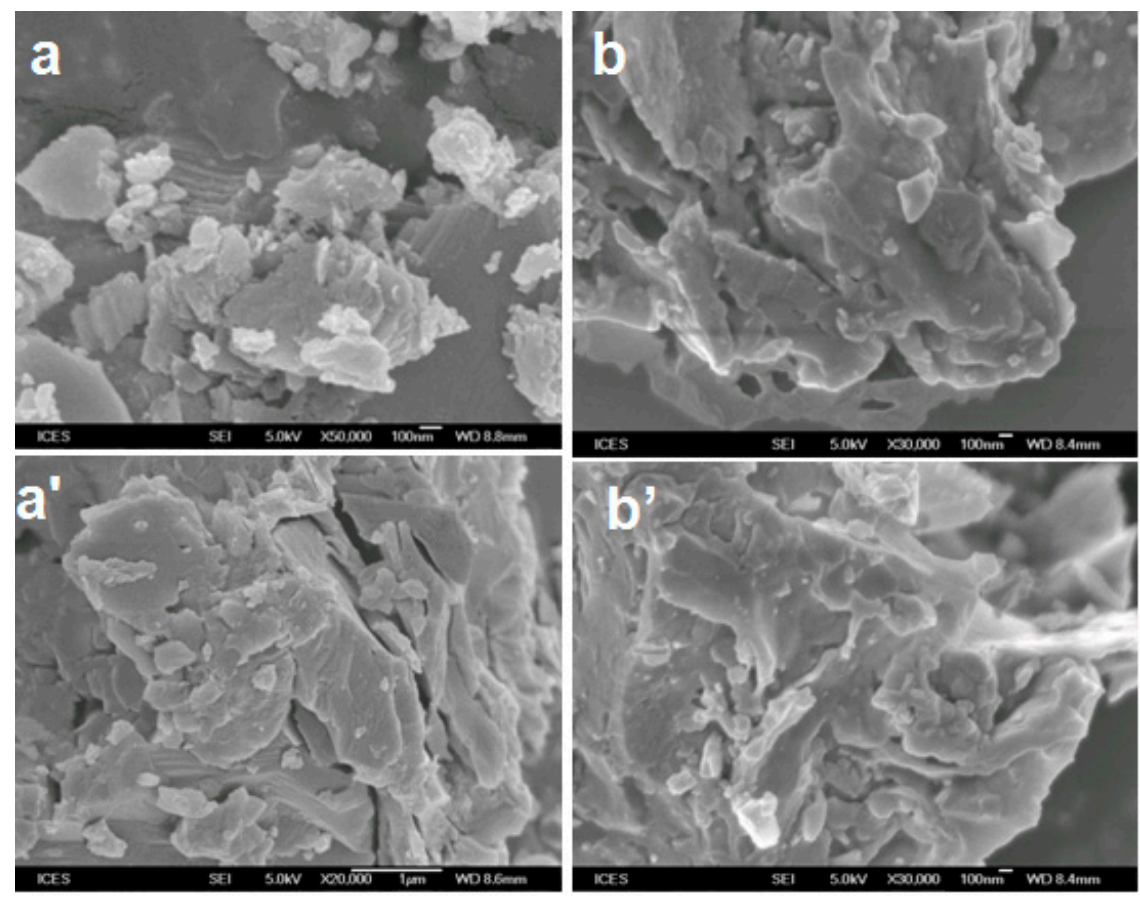

Figure 4. SEM micrographs of (a) Med-WB and (b) Jed-WB materials. ( $\left.\mathbf{a}^{\prime}\right)$ and $\left(\mathbf{b}^{\prime}\right)$ correspond to (a) and (b) after treatment with $\mathrm{NaOH}$ solution, respectively. 
The nitrogen adsorption isotherms exhibited a type II for both materials, characteristic of non-porous materials, the high adsorbed nitrogen volume was related to the capillary condensation of nitrogen gas at a higher relative pressure. The specific surface values were $1.00 \mathrm{~m}^{2} / \mathrm{g}$ and $2.76 \mathrm{~m}^{2} / \mathrm{g}$. These values are close to those reported for some waste bricks. [41,53]. The average pore size was about $7.90 \mathrm{~nm}$, confirming the non-porous character of these materials. When these WB were treated with the $\mathrm{NaOH}$ solution, a slight variation of $\mathrm{S}_{\mathrm{BET}}$ was observed, indicating that the later treatment did not effectively affect these materials, consistent with the XRF data and with the data reported for natural clays (Table 2). However, an increase of the pore volume and the average pore diameter were observed for the resulting Jed-WB.

Table 2. Microtextural properties of different waste bricks before and after treatment with the $\mathrm{NaOH}$ solution.

\begin{tabular}{cccc}
\hline Samples & $\mathbf{S}_{\text {BET }}\left(\mathbf{m}^{2} / \mathbf{g}\right)$ & P.V (cc/g) & A.P.D. $(\mathbf{n m})$ \\
\hline Jed-WB & 1.00 & 0.001 & 7.81 \\
Med-WB & 2.76 & 0.005 & 7.95 \\
B-Med * $^{*}$ & 3.77 & 0.003 & 4.60 \\
B-Jed $^{*}$ & 4.42 & 0.014 & 12.80 \\
\hline
\end{tabular}

* stands for sample treated with the $\mathrm{NaOH}$ solution. $\mathrm{S}_{\mathrm{BET}}$ : specific surface area, P.V.: average pore volume, A.P.D.: average pore diameter.

\subsection{Removal of Basic Blue Properties}

The particle size was reported to be a major factor in the removal properties of the used materials $[33,54,55]$ and the optimum size was in the range of $0.220 \mathrm{~mm} \pm 0.125 \mathrm{~mm}$ in diameter, according to the study carried out on the Med-WB material [33]. So, this size range was selected in this part for both WB materials.

\subsubsection{Effect of Initial Concentration}

The initial dye concentration provides an important driving force to overcome all mass transfer resistances of dye between the aqueous and solid phases [56,57].

The initial concentrations were varied in the range of $25 \mathrm{mg} / \mathrm{L}$ to $1000 \mathrm{mg} / \mathrm{L}$ and $0.1 \mathrm{~g}$ of WB was used at natural $\mathrm{pH}$ in this study. The removal percentage showed a decreasing trend as the initial dye concentration of the dye is increased. At lower concentrations, all basic blue 41 ions present in the medium could interact with the binding sites, resulting in higher dye removal (\%). At higher concentrations, the dye removal (\%) shows a decreasing behavior because of the saturation of the adsorption sites. The highest percentage of $100 \%$ was obtained for $C_{i}$ values between $25 \mathrm{mg} / \mathrm{L}$ to $150 \mathrm{mg} / \mathrm{L}$. It reached a value of $48 \%$ at higher $\mathrm{C}_{\mathrm{i}}$ values of $1000 \mathrm{mg} / \mathrm{L}$. However, the removal capacity of the WB materials for BB- 41 dye increased gradually as the initial concentration $\left(C_{i}\right)$ of BB- 41 dye increased from $25 \mathrm{mg} / \mathrm{L}$ to $1000 \mathrm{mg} / \mathrm{L}$ (Figure 5).

The Jed-WB had different removal properties than the Med-WB material (Figure 5) and it exhibited a lower removal capacity and percentage value. The maximum removal percentage, of $85 \%$, was achieved only at the $C_{i}$ of $25 \mathrm{mg} / \mathrm{L}$. This difference could be related to the specific surface area. However, this fact did not explain the reason behind such behavior. Indeed, the Jed-WB exhibited a higher specific surface area, compared to Med-WB, but it has a lower removal capacity. Similar studies indicated that the removal capacity was not related directly to the specific surface area values [33,58], however, it was related to the available removal sites on the surface of these materials. 


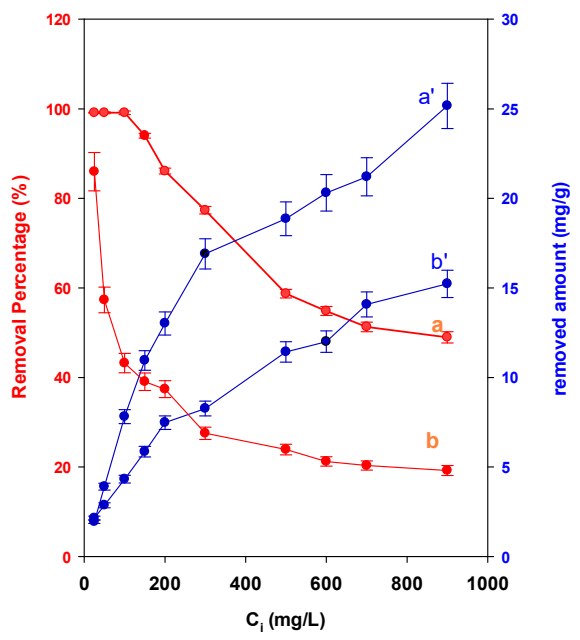

Figure 5. Effect of the initial concentrations $\left(\mathrm{C}_{\mathrm{i}}\right)$ of BB-41 on the removal percentage $(\%)$ and the removed amount $(\mathrm{mg} / \mathrm{g})$ using $\left(\mathrm{a}, \mathrm{a}^{\prime}\right)$ Med-WB and $\left(\mathrm{b}, \mathrm{b}^{\prime}\right)$ Jed-WB.

\subsubsection{Effect of WB Mass}

The dosage variation (used solid mass) provides an idea of the effectiveness of an adsorbent and the ability of a dye to be removed with a minimum dosage, so as to identify the ability of a dye from an economical point of view [58]. The effect of the WB mass on the removal of BB-41 was carried at $25^{\circ} \mathrm{C}$ with $200 \mathrm{mg} / \mathrm{L}$ of BB-41 solution. The WB dosage ranged from $0.010 \mathrm{~g}$ to $1 \mathrm{~g}$. Figure 6 presents the effect of the WB dosage on the removal efficiency of BB-41 dye. The removal percentage (\%) of BB-41 by the WB material was improved drastically, from $16 \%$ to $87 \%$, when the amount of Med-WB added increased from $0.25 \mathrm{~g}$ to $0.5 \mathrm{~g}$. Furthermore, the increase of used solid waste improved up to $0.7 \mathrm{~g}$ led to a maximum removal percentage of $99 \%$. This increase could be related to the increase in the removal sites, which make the removal of BB-41 easy until equilibrium. Removal of BB- 41 cations remained constant for further increases of $W B$ amounts above $0.7 \mathrm{~g}$. Similar behavior was observed using the Jed-WB, however, by adding higher amounts of Jed-WB, to $1 \mathrm{~g}$, the maximum of removal percentage was achieved and it was still lower than those obtained for Med-WB. These data confirmed that the aggregation or the overlapping of the removal sites could occur $[59,60]$.

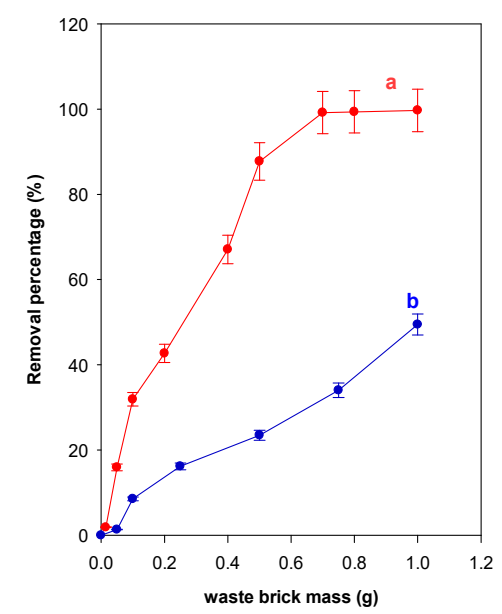

Figure 6. Effect of the used WB mass on the removal percentage of BB-41, (a) Med-WB and (b) Jed-WB.

\subsubsection{Effect of Removal Temperatures}

The removal process of BB-41, by different solids, was found to be an endothermic process or an exothermic process and the removal efficiency values depended on the temperature values $[33,61,62]$. 
The effect of the temperature has to be examined case by case. In this study, the amount of removed BB-41 was improved by increasing the temperature values for the Med-WB and Jed-WB. A maximum of $60 \mathrm{mg} / \mathrm{g}$ was reached for Med-WB, while, a lesser value of $35 \mathrm{mg} / \mathrm{g}$ were achieved in the case of the Jed-WB at the same temperature of $60^{\circ} \mathrm{C}$. These findings confirmed that the removal process was an endothermic process and the temperature effect was noticed clearly for Med-WB rather than for Jed-WB.

The thermodynamic parameters, such as standard Gibbs energy change $\left(\Delta \mathrm{G}^{\circ}\right)$, enthalpy change $\left(\Delta \mathrm{H}^{\circ}\right)$, and entropy change $\left(\Delta \mathrm{S}^{\circ}\right)$ are summarized in Table 3 and were determined as reported in a previous work [19]. These parameters provide further details on the spontaneity, feasibility, and sorbate-sorbent interactions during the of BB- 41 removal process.

Table 3. Thermodynamics of BB-41 removal using Med-WB and Jed-WB, respectively.

\begin{tabular}{|c|c|c|c|c|c|}
\hline Materials & $\begin{array}{c}\Delta \mathrm{H}^{\circ} \\
\left(\mathrm{kJ} \cdot \mathrm{mol}^{-1}\right)\end{array}$ & $\begin{array}{c}\Delta \mathrm{S}^{\circ} \\
\left(\mathrm{kJ} \cdot \mathrm{mol}^{-1} \cdot \mathrm{K}\right)\end{array}$ & \multicolumn{3}{|c|}{$\Delta \mathrm{G}^{\circ}\left(\mathrm{kJ} \cdot \mathrm{mol}^{-1}\right)$} \\
\hline \multirow{2}{*}{ Med-WB } & \multirow{2}{*}{135.12} & \multirow{2}{*}{0.45} & $303 \mathrm{~K}$ & $323 \mathrm{~K}$ & $333 \mathrm{~K}$ \\
\hline & & & -1.49 & -3.59 & -17.05 \\
\hline Jed-WB & 43.92 & 0.17 & -0.74 & -1.36 & -4.80 \\
\hline
\end{tabular}

The negative vales of $\Delta \mathrm{G}^{\circ}$ increased as temperature increased from 303 to $333 \mathrm{~K}$, suggesting an improved feasibility and spontaneity of the BB-41-waste brick system at elevated temperatures. The increase of $\Delta \mathrm{G}^{\circ}$ for Med-WB was more important compared to the BB-41-Jed-W. This difference could be related to the distribution of the removal sites on the waste surfaces. The positive value of $\Delta S^{\circ}$ showed that the removal process of BB-41 onto waste bricks was enhanced due to an increase in the degree of disorderliness at the sorbate-sorbent interface [63]. The values of $\Delta S^{\circ}$ were higher in the case of Med-W compared to the Jed-W, due to the higher amount of BB-41 accompanied with the higher mobility of the removed molecules on the surface [64]. The positive value of the heat of adsorption, $\Delta \mathrm{H}^{\circ}$, indicated that the process of adsorption was endothermic in nature, hence the amount of BB-41 removed by the waste bricks in the aqueous solution was favored at a higher temperature. This is in agreement with the results listed in Table 3. The value of $\Delta \mathrm{H}^{\circ}$ indicates the mechanism of adsorption to be either physisorption, when $\Delta \mathrm{H}^{\circ}$ is between 2.1 to $20.9 \mathrm{~kJ} \mathrm{~mol}^{-1}$, or chemisorption, when $\Delta \mathrm{H}^{\circ}$ is between 80 to $200 \mathrm{~kJ} \mathrm{~mol}^{-1}[65,66]$. From Table 3, the estimated value of $\Delta \mathrm{H}^{\circ}$ lies between 51 to $135 \mathrm{~kJ} \mathrm{~mol}^{-1}$, suggesting that the mechanism of interaction between BB-41 and waste bricks in water is mainly governed by the ion exchange process and the chemisorption process [67].

\subsubsection{Effect of the $\mathrm{pH}$ of the Basic Blue- 41 Solution}

The $\mathrm{pH}$ value plays an important factor during the removal process. It does not alter the adsorbent site dissociation, however, it alters the chemistry and the structure of the dye. The latter could be achieved by adding $\mathrm{HCl}$ or $\mathrm{NaOH}$ solutions to the dye solution $[67,68]$.

Figure 7 indicates that the removal efficiency of Med-WB was improved when the $\mathrm{pH}$ of the solution was increased from 2 to 3.05. Further increase of $\mathrm{pH}$ did not significantly change the removal percentage and it was about $99 \%$. In the case of Jed-WB material, the $\mathrm{pH}$ of the BB- 41 solution modified the removal percentage, however, in a certain extent, it was raised from $13 \%$ to $37 \%$ at a $\mathrm{pH}$ value of 9.3 . When the $\mathrm{pH}$ value was greater than 10, the BB-41 was unstable and, hence, no further investigation was conducted $[33,68]$. The high percentage obtained at higher $\mathrm{pH}$ values indicated the increase of the negative charge density of the waste brick, and thus, the electrostatic interaction between these charges and the positively charged dyes (see paragraph 3.2.5.). Another explanation could be associated with the dimerization of basic blue at higher concentrations [69] or to the reaction of BB-41with the $\mathrm{NaOH}$ solution. To confirm that, a solution of $\mathrm{NaOH}$ was added to a solution of $\mathrm{BB}-41$ at a pH higher than 9, without adding waste brick. The color of the solution was monitored over time and showed a change in its intensity over time until it became clear after two days. Similar observations were reported for 
the methylene blue dye solution [39]. The lower removal efficiency at acidic values could be associated with the excess of proton ions in the solution and, as a consequence, could compete with the basic dye cations on the removal sites of waste brick materials [30]. This assumption seemed to be valid in the case of Jed-WB. However, in the case of Med-WB, the highest removal of BB-41 was achieved at a pH value of 3 , indicating other effects could contribute to this behavior.

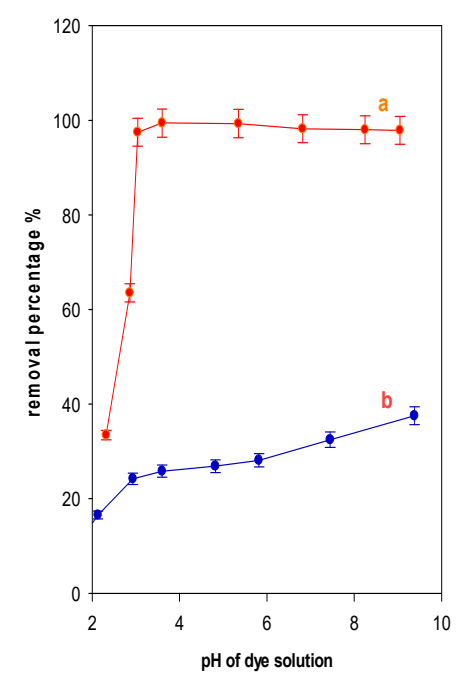

Figure 7. Effect of the BB-41 pH solution on the removal percentage of (a) Med-WB and (b) Jed-WB materials.

\subsubsection{Effect of WB Modification}

As reported in previous paragraph, the higher uptake of BB-41 was achieved at higher $\mathrm{pH}$ values of the BB-41 solution. In this part, the $\mathrm{WB}$ materials were treated with a $\mathrm{NaOH}$ solution prior to the removal tests and the BB-41 solution was used at its natural value (without adjustment). The removal of the WB improved after the $\mathrm{NaOH}$ treatment, especially for Jed-WB, with a maximum of $16 \mathrm{mg} / \mathrm{g}$. However, it was still lower than the Med-WB ( $38 \mathrm{mg} / \mathrm{g}$ ) (Figure 8). The improvement could be related to the improvement of the $S_{\mathrm{BET}}$ values, however, there was slight variation of these values after the $\mathrm{NaOH}$ treatment, as presented in Table 2.

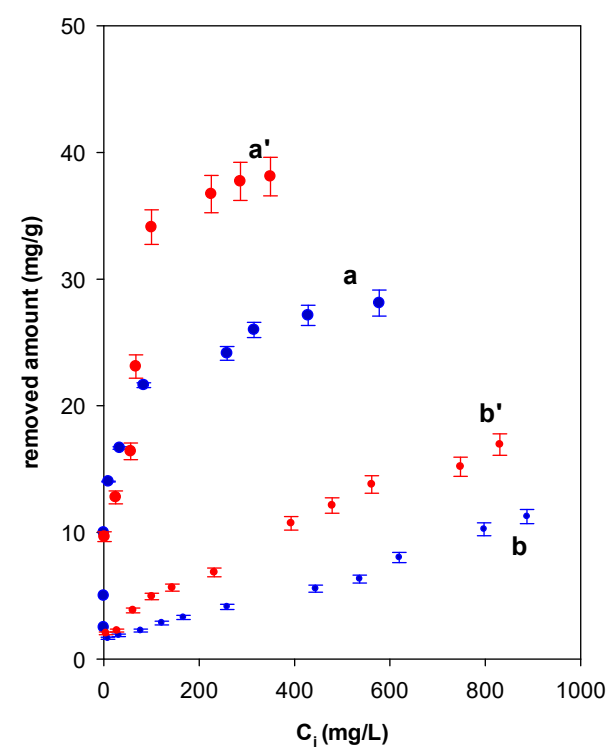

Figure 8. Effect of $\left(\mathbf{a}^{\prime}, \mathbf{b}^{\prime}\right)$ base treatment of $(\mathbf{a}, \mathbf{b})$ Med-WB and Jed-WB, respectively, on the removed amount of BB-41 dye. 
The increase of removal efficiency was related to the surface properties. At a lower $\mathrm{pH}$ the surface of the silica becomes positively charged, whilst at a higher $\mathrm{pH}$ it becomes negatively charged [70]. In our case, the increase of the number of negatively charged sites on the WB materials when treated with $\mathrm{NaOH}$ solution enhanced the electrostatic attraction between the BB-41 cations (positively charged) and the negatively charged surface of the WB materials [71].

At a lower $\mathrm{pH}$, the adsorption of the cationic dye should be less because of the lower dissociation of the dye molecules, as well as the positively-charged surface [70]. At a higher $\mathrm{pH}$, both the dye and the surface will be dissociated, which results in a higher adsorption through increased cation exchange capabilities.

\subsection{Langmuir Isotherm and Maximum Removal Capacity}

The performance of an adsorbent can be studied by adsorption isotherm data. Modeling the adsorption isotherm data is an essential way for predicting and comparing the adsorption performance, which is critical for optimization of the adsorption mechanism pathways, expression of the adsorbents capacities, effective design, and applicable practice of the adsorption systems [72]. The Langmuir isotherm model was used to evaluate the maximum removal capacity of the different materials such as waste bricks [33], organoclays [58], and zeolite materials [73]. The linear equation of the Langmuir model is presented in the following Equation (1) [74]:

$$
\frac{C_{e}}{q_{e}}=\frac{1}{q_{\max } \cdot K_{L}}+\frac{C_{e}}{q_{\max }} .
$$

A straight line with a slope of $1 / q_{m}$ and an intercept of $1 / q_{m} K_{L}$ is obtained when $C_{e} / q_{e}$ is plotted against $\mathrm{C}_{\mathrm{e}}$. Table 4 summarizes the values of these parameters. The regression coefficients are in order of 0.994 to 0.997 , indicating the feasibility of the model to determine the maximum removal capacities of different materials, and confirming the monolayer coverage of dye onto WB particles.

Table 4. Langmuir parameters of the BB-41 removal by different brick wastes and at different conditions.

\begin{tabular}{|c|c|c|c|}
\hline Samples & $\mathrm{q}_{\mathrm{m}}\left(\mathrm{mg} \cdot \mathrm{g}^{-1}\right)$ & $K_{L}\left(L \cdot g^{-1}\right)$ & $\mathbf{R}^{2}$ \\
\hline Med-WB & 29.01 & 0.096 & 0.9932 \\
\hline Jed-WB & 16.81 & 0.007 & 0.9861 \\
\hline Med-WB- $30{ }^{\circ} \mathrm{C}$ & 32.15 & 0.234 & 0.9885 \\
\hline Jed-WB- $30{ }^{\circ} \mathrm{C}$ & 20.83 & 0.004 & 0.9787 \\
\hline Med-WB- $50{ }^{\circ} \mathrm{C}$ & 34.89 & 0.256 & 0.9861 \\
\hline Jed-WB- $50{ }^{\circ} \mathrm{C}$ & 30.03 & 0.060 & 0.9932 \\
\hline Med-WB- $60{ }^{\circ} \mathrm{C}$ & 58.47 & 0.439 & 0.9975 \\
\hline Jed-WB- $60{ }^{\circ} \mathrm{C}$ & 36.40 & 0.053 & 0.9767 \\
\hline B-Med-WB & 43.50 & 0.210 & 0.9962 \\
\hline B-Jed-WB & 34.36 & 0.029 & 0.9654 \\
\hline
\end{tabular}

The Med-WB exhibited higher removal capacities at different conditions compared to the Jed-WB. By increasing the removal temperatures, the efficiency of the waste bricks was further improved and a maximum of $120 \mathrm{mg} / \mathrm{g}$ was achieved for the Med WB, at $60{ }^{\circ} \mathrm{C}$. However, the Jed WB material exhibited a removal of $42 \mathrm{mg} / \mathrm{g}$ even at $60^{\circ} \mathrm{C}$. The treatment of the waste brick by $\mathrm{NaOH}$ also modified the removal properties and an increase of $35 \%$ to $50 \%$ was achieved.

The Langmuir constant $\left(\mathrm{K}_{\mathrm{L}}\right)$ indicates the extent of the interaction between the adsorbate and the surface. If the value of $\mathrm{K}_{\mathrm{L}}$ is relatively larger it indicates that there is a strong interaction between adsorbate and adsorbent, while a smaller value implies a weak interaction. In our case, the values were quite low and reflected the weak affinity of the BB-41 dye to the surface of the WB materials (Table 4). 
The investigated waste bricks materials have a good efficiency for this dye, compared to other silicate materials (Table 5). The local clays exhibited the highest removal amount because they were not calcined at high temperatures and were used as received.

Table 5. Comparison of the maximum removed amount $\left(\mathrm{q}_{\max }\right)$ of BB-41 by different materials.

\begin{tabular}{ccc}
\hline Samples & $\mathbf{q}_{\max }(\mathbf{m g} / \mathbf{g})$ & Reference \\
\hline Med-WB & 30.03 & {$[33]$} \\
Jed-WB & 16.80 & This study \\
B-Med-WB & 43.50 & {$[33]$} \\
B-Jed-WB & 34.36 & This study \\
Kaolinite & 6.20 & {$[73]$} \\
Hydroxysodalite & 39.37 & {$[73]$} \\
Zeolite -X & 17.69 & {$[73]$} \\
Zeolite Y & 26.80 & {$[73]$} \\
Local Clay & 73.00 & {$[19]$} \\
Acid-activated local clays & 50.34 & {$[19]$} \\
\hline
\end{tabular}

\subsection{Regeneration Properties}

The regeneration process is considered an important step for the feasibility of an adsorbent and it is considered as important issue that needs to be addressed, otherwise, the used materials would create a new round of environmental problems with the disposal issues. A number of regeneration methods were summarized and discussed in recent reviews [23,75]. In this study, a regeneration method was adopted with an efficient, eco-friendly, and easy to operate process, to reuse the spent waste bricks $[19,76]$. The treatment of fresh spent waste bricks was done after the first removal of basic blue 41 by a solution containing cobalt cations and an oxidant oxone. The $\mathrm{Co}^{2+}$ cations served as the homogeneous catalyst. The oxidant oxone was used to degrade the removed dye [77]. In a previous study, the concentrations initially used affected the removal efficiency during the regeneration process.

In this case, two initial concentrations (50 ppm and $200 \mathrm{ppm}$ ) were used to study the regeneration process. The obtained data are presented in Figure $9 \mathrm{~A}, \mathrm{~A}^{\prime}$, and indicate that the removal efficiency of BB-Med-WB was maintained after four cycles of regeneration, with a small reduction of $10 \%$, compared to the fresh used Med-WB, using a BB- $41 C_{i}$ of $50 \mathrm{ppm}$. In the case of BB-Jed-WB, it behaved differently and the removal percentage dropped significantly, with a decrease of $25 \%$ in the fourth cycle. After 6 cycles of regeneration, the BB-Med-WB exhibited a removal percentage of $80 \%$ and $30 \%$ for Jed-WB. Using a high $C_{i}$ value of $200 \mathrm{mg} / \mathrm{L}$ (Figure $9 \mathrm{~A}^{\prime}$ ), the used waste bricks lost their efficiency after the third recycle, with a reduction of $15 \%$ and $36 \%$ for Med-WB and Jed-WB, respectively. Further regeneration led a continuous decrease of the removal efficiency, up to $50 \%$ and $80 \%$ of their initial values. This reduction could indicate that the adsorption sites lost their activities due to the non-decomposition of the removed BB-41 cations on the surface of the WB materials during the regeneration process. 
A

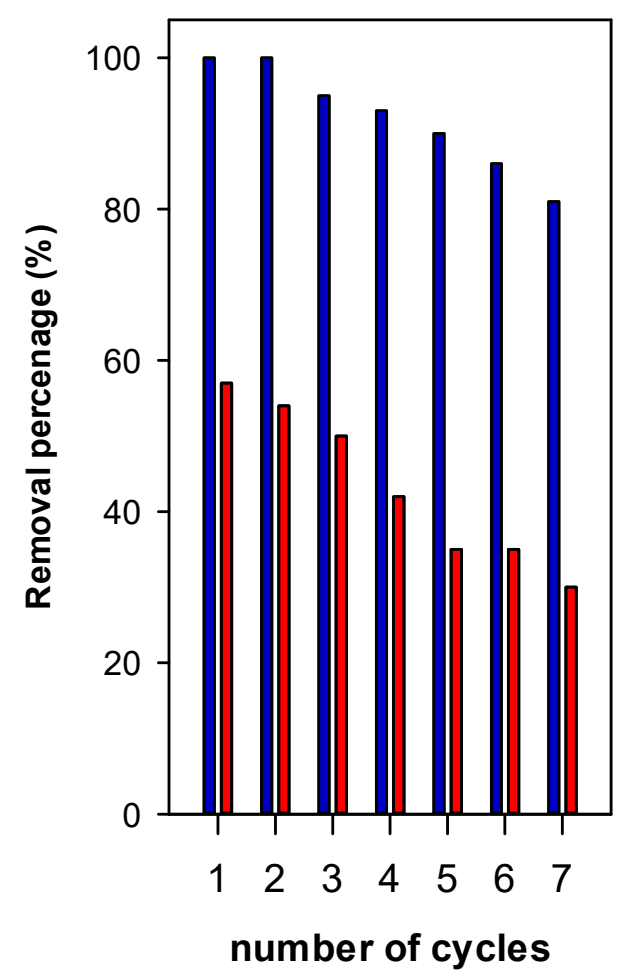

$A^{\prime}$

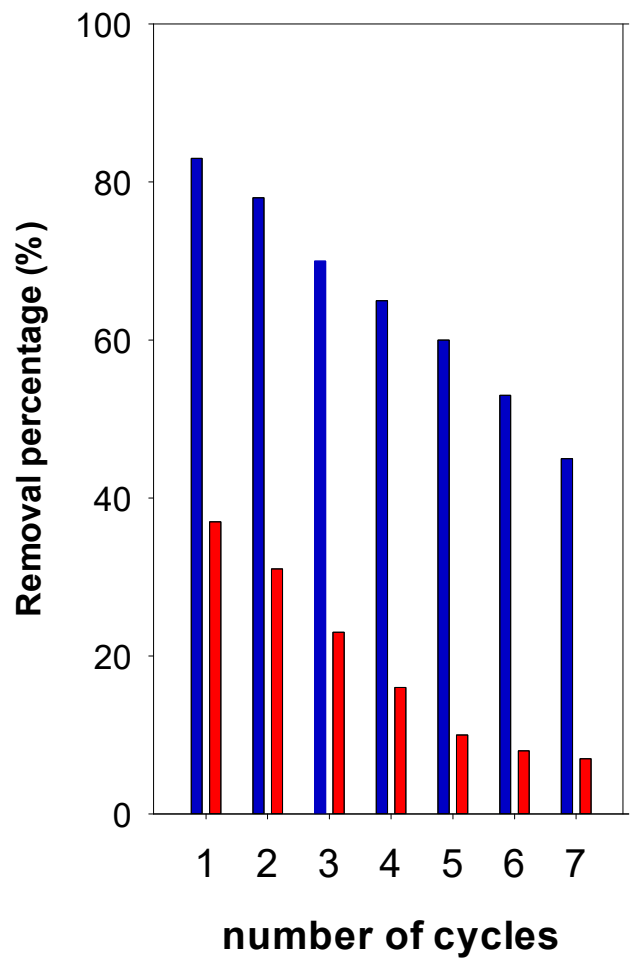

Figure 9. Regeneration/reuse of WB materials at different $C_{i}$ of BB-41: (A) 50 ppm and (A') 200 ppm. (Blue bars: Med-WB and red bars: Jed-WB).

\section{Conclusions}

The use of waste bricks was proposed as an efficient removal agent for basic blue 41 dyes from an aqueous solution. These removal properties were mainly affected by the initial concentration, $\mathrm{pH}$ value, temperature, and the treatment of the WB by a base solution. The temperature and the base treatment of the WB improved the removal capacities of both waste materials with a maximum of $60 \mathrm{mg} / \mathrm{g}$ for Med-WB and $32 \mathrm{mg} / \mathrm{g}$ for Jed-WB. For a low initial concentration of $50 \mathrm{ppm}$, the regeneration experiments indicated the removal efficiency was maintained after four cycles, with reductions of $25 \%$ and $50 \%$ for Med-WB and Jed-WB, respectively. However, using a high initial concentration of $200 \mathrm{ppm}$, the regeneration tests indicated that the removal was further decreased and it could be related to the hindering of the removal sites during the removal process. The origin of the waste bricks affected their removal characteristics and this study indicated that the origin of these wastes would be taken into account before their promotion.

Author Contributions: Conceptualization, F.K.; Data curation, Y.L., M.A. and H.O.H.; Formal analysis, F.K., H.O.H. and S.R.; Funding acquisition, M.A.; Investigation, F.K.; Methodology, F.K., Y.L., M.A., H.O.H., S.R., S.M.I. and Fahd Al Wadaani; Resources, F.K., Y.L., S.M.I. and F.A.W.; Supervision, F.K. and Y.L.; Validation, S.R. and F.A.W.; Writing - original draft, F.K.; Writing - review \& editing, S.M.I.

Funding: This research received no external funding

Conflicts of Interest: The authors declare no conflit of interest.

\section{References}

1. Gleick, P.H. An introduction to global fresh water issues. In Water in Crisis; Gleick, P.H., Ed.; Oxford University Press: New York, NY, USA, 1993; pp. 3-12.

2. Somlyody, L.; Varis, O. Freshwater under pressure. Int. Rev. Environ. Strateg. 2006, 6, 181-204. 
3. Bixio, D.; Thoeye, C.; Wintgens, T.; Ravazzini, A.; Miska, V.; Muston, M.; Chikurel, H.; Aharoni, A.; Joksimovic, D.; Melin, T. Water reclamation and reuse: Implementation and management issues. Desalination 2008, 218, 13-23. [CrossRef]

4. Baughman, G.L.; Perenich, T.A. Fate of dyes in aquatic systems: I. Solubility and partitioning of some hydrophobic dyes and related compounds. Environ. J. Toxicol. Chem. 1988, 7, 183-199. [CrossRef]

5. Bae, J.S.; Freeman, H.S. Aquatic toxicity evaluation of new direct dyes to the Daphnia magna. Dyes Pigment. 2007, 73, 81-85. [CrossRef]

6. De Sousa, M.L.; de Moraes, P.B.; Matos Lopes, P.R.; Montagnolli, R.N.; de Angelis, D.d.F.; Bidoia, E.D. Contamination by remazol red brilliant dye and its impact in aquatic photosynthetic microbiota. Environ. Mag. Sustain. Dev. 2012, 1, 129-138.

7. Robinson, T.; McMullan, G.; Marchant, R.; Nigam, P. Remediation of dyes in textile effluent: A critical review on current treatment technologies with a proposed alternative. Bioresour. Technol. 2001, 77, $247-255$. [CrossRef]

8. Garg, V.K.; Gupta, R.; Yadav, B.; Kumar, R. Removal of acid dyes by low cost adsorbent. Bioresour. Technol. 2003, 89, 121-124. [CrossRef]

9. Vital, R.K.; Saibaba, K.V.N.; Shaik, K.B. Dye Removal by Adsorption: A Review. J. Bioremediat. Biodegrad. 2016, 7, 371-374.

10. Sanghi, R.; Bhattacharaya, B. Review on decolourization of aqueous dye solution by low cost adsorbents. Color. Technol. 2002, 118, 256-269. [CrossRef]

11. Dawood, S.; Sen, T.K. Review on Dye Removal from Its Aqueous Solution into Alternative Cost Effective and Non-Conventional Adsorbents. J. Chem. Process. Eng. 2014, 1, 1-7.

12. Benalia, A.; Derbal, K.; Panico, A.; Piroz, F. Use of Acorn Leaves as a natural coagulant in a drinking water treatment plant. Water 2019, 11, 57. [CrossRef]

13. Hu, Q.H.; Qiao, S.Z.; Haghseresht, F. Adsorption study for the removal of basic red dye using bentonite. Ind. Eng. Chem. Res. 2006, 45, 733-738. [CrossRef]

14. Dogan, M.; Karaoglu, M.H.; Alkan, M. Adsorption kinetics of maxillon yellow 4GL and maxilon red GRL dyes on kaolinite. J. Hazard. Mater. 2009, 165, 1142-1151. [CrossRef]

15. Adeyemo, D.A.; Adeoye, I.O.; Bello, O.S. Adsorption of dyes using different types of clay: A review. Appl. Water Sci. 2017, 7, 543-568. [CrossRef]

16. Al-Asheh, S.; Abu-Aitah, B.F. The removal of methylene blue dye using activated and non-activated bentonite solutions. Adsorpt. Sci. Technol. 2003, 21, 451-462. [CrossRef]

17. Hsu, Y.C.; Chiang, C.C.; Yu, M.F. Adsorption behavior of basic dyes on activated clay. Sep. Sci. Technol. 1997, 32, 2513-2534. [CrossRef]

18. Kooli, F.; Liu, Y.; Al-Faze, R.; Al Suhaimi, A. Effect of acid activation of Saudi local clay mineral on removal properties of basic blue 41 from an aqueous solution. Appl. Clay Sci. 2015, 116-117, 23-30. [CrossRef]

19. Kooli, F.; Liu, Y.; Abboudi, M.; Rakass, S.; Oudghiri Hassani, H.; Ibrahim, S.M.; Al-Faze, R. Removal Properties of Anionic Dye Eosin by Cetyltrimethylammonium Organo-Clays: The Effect of Counter-Ions and Regeneration Studies. Molecules 2018, 23, 2364. [CrossRef]

20. Gil, A.; Assis, F.C.C.; Albeniz, S.; Korili, S.A. Removal of dyes from wastewaters by adsorption on pillared clays. Chem. Eng. J. 2011, 168, 1032-1040. [CrossRef]

21. Monash, P.; Pugazhenthi, G. Removal of Crystal Violet dye from aqueous solution using calcined and uncalcined mixed clay adsorbents. Sep. Sci. Technol. 2009, 45, 94-104. [CrossRef]

22. Vimonses, V.; Jin, B.; Chow, C.W.K.; Saint, C. Enhancing removal efficiency of anionic dye by combination and calcination of clay materials and calcium hydroxide. J. Hazard. Mater. 2009, 171, 941-947. [CrossRef]

23. Momina; Shahadat, M.; Isamil, S. Regeneration performance of clay-based adsorbents for the removal of industrial dyes: A review. RSC Adv. 2018, 8, 24571-24587. [CrossRef]

24. Cheng, H. Reuse research progress on waste clay brick. Procedia Environ. Sci. 2016, 31, 218-226. [CrossRef]

25. Demir, I.; Orhan, M. Reuse of waste bricks in the production line. Build. Environ. 2003, 38, 1451-1455. [CrossRef]

26. Naceri, A.; Hamina, M.C. Use of waste brick as a partial replacement of cement in mortar. J. Waste Manag. 2009, 29, 2378-2384. [CrossRef] [PubMed]

27. Labidi, N.S. Removal of Mercury from Aqueous Solutions by Waste Brick. Int. J. Environ. Res. 2008, 2, 275-278. 
28. Yadav, A.K.; Kaushik, C.P.; Haritash, A.K.; Kansal, A.; Rani, N. Defluoridation of groundwater using brick powder as an adsorbent. J. Hazard. Mater. 2006, 128, 289-293. [CrossRef] [PubMed]

29. Jia, C.; Dai, Y.; Chang, J.; Wu, C.; Wu, Z.; Liang, W. Adsorption characteristics of used brick for phosphorus removal from phosphate solution. Desalin. Water Treat. 2013, 51, 5886-5891. [CrossRef]

30. Hamdaoui, O. Batch Study of liquid-phase adsorption of methylene blue using cedar sawdust and crushed brick. J. Hazard. Mater. 2006, B135, 264-273. [CrossRef]

31. El-Shahat, M.F.; Shehata, A.M.A. Adsorption of lead, cadmium and zinc ions from industrial wastewater by using raw clay and broken clay-brick waste. Asian J. Chem. 2013, 25, 4284-4288. [CrossRef]

32. Zhang, Z.; Li, Y.; Chen, H.; Zhang, X.; Li, H. The systematic adsorption of diclofenac onto waste red bricks functionalized with iron oxides. Water 2018, 10, 1343. [CrossRef]

33. Kooli, F.; Yan, L.; Al-Faze, R.; Al-Sehimi, A. Removal enhancement of basic blue 41 by waste brick from an aqueous solution. Arab. J. Chem. 2015, 8, 333-342. [CrossRef]

34. Dehou, C.; Wartel, M.; Recourt, P.; Revel, B.; Mabingui, J.; Montiel, A.; Boughriet, A. Physicochemical crystalline and morphological characteristics of bricks used for ground waters purification in Bangui region (Central African Republic). Appl. Clay Sci. 2012, 59, 69-75. [CrossRef]

35. Cheng, H.P.; Huanga, Y.H.; Leeb, C. Decolorization of reactive dye using a photo-ferrioxalate system with brick grain-supported iron oxide. J. Hazard. Mater. 2011, 188, 357-362. [CrossRef]

36. Fatimah, I.; Fadillah, $\mathrm{S}$. $\mathrm{TiO}_{2}$ supported on brick waste as low cost photocatalyst for dye photodegradation. Chem. Eng. Trans. 2018, 63, 733-738.

37. Rouquerol, J.; Llewellyn, P.; Sing, K. Adsorption by Clays, Pillared Clays, Zeolites and Aluminophosphates; Springer: Oxford, UK, 2014; pp. 467-527.

38. Aboudi Mana, S.C.; Hanafiah, M.M.; Chowdhury, A.J.K. Environmental characteristics of clay and clay-based minerals. Geol. Ecol. Landsc. 2017, 1, 155-161. [CrossRef]

39. Pires, J.; Machado, M.; de Carvalho, M.B. Porosity and thermal stability of PILCs prepared with clays from different origins and different metal-polyhydroxycationic species ofAl and Al/Ce. J. Mater. Chem. 1998, 8, 1465-1469. [CrossRef]

40. Munoz, H.J.; Blanco, C.; Gil, A.; VVicente, M.A.; Galeano, L.A. Preparation of Al/Fe-Pillared Clays: Effect of the Starting Mineral. Materials 2017, 10, 1364. [CrossRef] [PubMed]

41. Tsozué, D.; Nzeugang, A.N.; Mache, J.R.; Loweh, S.; Fagel, N. Mineralogical, physico-chemical and technological characterization of clays from Maroua (Far-North, Cameroon) for use in ceramic bricks production. J. Build. Eng. 2017, 11, 17-24. [CrossRef]

42. Chin, C.L.; Ahmad, Z.A.; Sow, S.S. Relationship between the thermal behaviour of the clays and their mineralogical and chemical composition: Example of Ipoh, Kuala Rompin and Mersing (Malaysia). Appl. Clay Sci. 2017, 143, 327-335. [CrossRef]

43. Campbell, J.W.P.; Pryce, W. Brick: A World History; Thames and Hudson: New York, NY, USA, 2003.

44. Hussin, F.; Aroua, M.K.; Daud, W.M.A.W. Textural characteristics, surface chemistry and activation of bleaching earth: A review. Chem. Eng. J. 2011, 170, 90-106. [CrossRef]

45. Kooli, F.; Liu, Y.; Tan, S.X.; Zheng, J. Organoclays from alkaline-treated acid-activated clays. J. Therm. Anal. Calorim. 2014, 115, 1465-1475. [CrossRef]

46. Song, J.G.; Wang, F.; Bai, X.B.; Du, D.M.; Ju, Y.Y.; Xu, M.H.; Ji, G.-C. Effect of the sintering technology on the properties of fired brick from quartz sand. J. Ceram. Proc. Res. 2011, 12, 357-360.

47. Russell, J.D. A Hand Book of Determinative Methods in Clay Mineralogy; Wilson, M.J., Ed.; Blackie and Son Ltd.: Glasgow, UK, 1987.

48. Percival, H.J.; Duncan, J.F.; Fosters, P.K. Interpretation of the Kaolinite-Mullite Reaction Sequence from Infrared Absorption Spectra. J. Am. Ceram. Soc. 1974, 57, 57-64. [CrossRef]

49. Nirmala, G.; Viruthagiri, G. FT-IR characterization of articulated ceramic bricks with wastes from ceramic industries. Spectrochim. Acta A Mol. Biomol. Spectrosc. 2014, 126, 129-134. [CrossRef]

50. Addadi, L.; Raz, S.; Weiner, S. Taking advantage of disorder: Amorphous calcium carbonate and its role in biomineralization. Adv. Mater. 2003, 15, 960-970. [CrossRef]

51. Ghosh, S.N. Infra-red spectra of some selected minerals, rocks and products. J. Mater. Sci. 1978, 13, 1877-1886. [CrossRef]

52. Khouzani, M.F.; Chevrier, D.M.; Güttlein, P.; Hauser, K.; Zhang, P.; Hedin, N.; Gebauer, D. Disordered amorphous calcium carbonate from direct precipitation. Cryst. Eng. Comm. 2015, 17, 4842-4849. [CrossRef] 
53. Dehou, S.C.; Wartel, M.; Recourt, P.; Revel, B.; Boughriet, A. Acid Treatment of Crushed Brick (from Central African Republic) and Its Ability (after FeOOH Coating) to Adsorb Ferrous Ions from Aqueous Solutions. Open Mater. Sci. J. 2012, 6, 50-59. [CrossRef]

54. Reyad, A.; Shawabkeh, R.A.; Tutunji, M.F. Experimental study and modeling of basic dye sorption by diatomaceous clay. Appl. Clay Sci. 2003, 24, 111-120.

55. Khraisheh, M.A.; Al-Ghouti, M.A.; Allen, S.J.; Ahmad, M.N. The effect of pH, temperature, and molecular size on the removal of dyes from textile effluent using manganese oxides-modified diatomite. Water Environ. Res. 2004, 76, 2655-2663. [CrossRef]

56. Shahryari, Z.; Goharrizi, A.S.; Azadi, M. Experimental study of methylene blue adsorption from aqueous solutions onto carbon nanotubes. Int. J. Water Resour. Environ. Eng. 2010, 2, 216-280.

57. Sharma, P.; Kaur, R.; Baskar, C.; Chung, W.J. Removal of methylene blue from aqueous waste using rice husk and rice husk ash. Desalination 2010, 259, 249-257. [CrossRef]

58. Kooli, F.; Liu, Y.; Hbaieb, K.; Ching, O.Y.; Al-Faze, R. Characterization of organo-kenyaites: thermal stability and their effects on eosin removal characteristics. Clay Miner. 2018, 53, 91-104. [CrossRef]

59. Annadurai, G.; Juang, R.S.; Lee, D.J. Use of cellulose-based wastes for adsorption of dyes from aqueous solutions. J. Hazard. Mater. 2002, 92, 263-274. [CrossRef]

60. Regti, A.; Laamari, M.R.; Stiriba, S.; El Haddad, M. Removal of Basic Blue 41 dyes using Persea americana-activated carbon prepared by phosphoric acid action. Int. J. Ind. Chem. 2017, 8, 187-195. [CrossRef]

61. Mehrizi, M.Z.; Badiei, A. Highly efficient removal of Basic Blue 41 with nanoporous silica. Water Resour. Ind. 2014, 5, 49-57. [CrossRef]

62. Abul Hossain, M.; Mohibullah, M. Kinetics and thermodynamics of adsoprtion of basic Blue 41 on used black tea leaves. Int. J. Sci. Res. 2017, 8, 995-1002.

63. Meroufel, B.; Benali, O.; Benyahia, M.; Benmoussa, Y.; Zenasni, M.A. Adsorptive removal of anionic dye from aqueous solutions by Algerian kaolin: Characteristics, isotherm, and thermodynamic studies. J. Mater. Environ. Sci. 2013, 4, 482-491.

64. Gupta, V.K.; Jain, R.; Siddiqui, M.N.; Saleh, T.A.; Agarwal, S.; Malati, S.; Pathak, D. Equilibrium and thermodynamic studies on the adsorption of the dye. J. Chem. Eng. Data 2010, 55, 5225-5229. [CrossRef]

65. Liu, Y.; Liu, Y.J. Biosorption isotherms, kinetics and thermodynamics. Sep. Purif. Technol. 2008, 61, $229-242$. [CrossRef]

66. Ma, J.; Jia, Y.; Jing, Y.; Yao, Y.; Sun, J. Kinetics and thermodynamics of methylene blue adsorption by cobalt-hectorite composite. Dyes Pigment. 2012, 93, 1441-1446. [CrossRef]

67. Alver, E.; Metin, A.U. Anionic dye removal from aqueous solutions using modified zeolite: Adsorption kinetics and isotherm studies. Chem. Eng. J. 2012, 200-202, 59-67. [CrossRef]

68. Humelnicu, I.; Baiceanu, A.; Ignat, M.E.; Dulman, V. The removal of basic blue 41 textile dye from aqueous solution by adsorption onto natural zeolitic tuff: Kinetics and thermodynamics. Process Saf. Environ. Prot. 2017, 105, 274-287. [CrossRef]

69. Atar, M.; Olgun, A.; Colak, F. Thermodynamic, equilibrium and kinetic study of the biosorption of Basic Blue 41 using Bacillus macerans. Eng. Life Sci. 2008, 8, 499-506. [CrossRef]

70. Roulia, M.; Vassiliadis, A.A. Interactions between C.I. basic blue 41 and aluminosilicate sorbents. J. Colloid Interface Sci. 2005, 292, 37-44. [CrossRef] [PubMed]

71. Ahmed, M.N.; Ram, R.N. Removal of basic dye from waste-water using silica as adsorbent. Environ. Pollut. 1992, 77, 79-86. [CrossRef]

72. Dove, P.M.; Rimstidt, J.D. Silica-water interactions. Silica reviews in Mineralogy. Miner. Soc. Am. 1994, 29, 259-307.

73. Gougazeh, M.; Kooli, F.; Buhl, J.C. Removal efficiency of basicblue41 by three zeolites prepared from natural Jordanian kaolinite. Accept. Clays Clay Miner. 2019.

74. Langmuir, I. The constitution and fundamental properties of solids and liquids. J. Am. Chem. Soc. 1916, 39, 2221-2295. [CrossRef]

75. Zhu, R.; Zhu, J.; Ge, F.; Yuan, P. Regeneration of spent organoclays after the soprtion of organic pollutants: A review. J. Environ. Manag. 2009, 90, 3212-3216. [CrossRef] [PubMed] 
76. Kooli, F.; Liu, Y.; Abboudi, M.; Rakass, S.; Oudghiri Hassani, H.; Ibrahim, S.M.; Al-Faze, R. Application of Organo-Magadiites for the Removal of Eosin Dye from Aqueous Solutions: Thermal Treatment and Regeneration. Molecules 2018, 23, 2280. [CrossRef] [PubMed]

77. Anipsitakis, G.P.; Dionysiou, D.D.; Gonzalez, M.A. Cobalt-mediated activation of peroxymonosulfate and sulfate radical attack on phenolic compounds. Implications of chloride ions. Environ. Sci. Technol. 2006, 40, 1000-1007. [CrossRef] [PubMed]

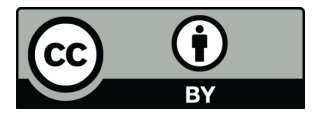

(C) 2019 by the authors. Licensee MDPI, Basel, Switzerland. This article is an open access article distributed under the terms and conditions of the Creative Commons Attribution (CC BY) license (http:/ / creativecommons.org/licenses/by/4.0/). 